\title{
Kinerja Cabinet Dryer pada Pengeringan Jahe Merah dengan Memanfaatkan Panas Terbuang Kondensor Pendingin Udara
}

\section{Performance of Cabinet Dryer in the Red Ginger Drying by Utilizing the Waste Heat of Air Conditioner Condenser}

\author{
Nunik Lestari $^{1 *}$, Samsuar $^{2)}$, Ervi Novitasari ${ }^{1)}$, dan Khaidir Rahman ${ }^{1)}$ \\ 1)* Program Studi Pendidikan Teknologi Pertanian, Fakultas Teknik, Universitas Negeri Makassar \\ 2) Program Studi Keteknikan Pertanian, Fakultas Pertanian, Universitas Hasanuddin \\ ${ }^{*}$ E) E-mail korespondensi: nunik.lestari@unm.ac.id
}

\begin{abstract}
Red ginger is rich in antioxidants and active ingredients, so the drying process should be carried out using low temperatures. Drying red ginger at low temperatures can be done using a cabinet dryer whose heating source comes from the wasted heat of the AC condenser. The purpose of this study was to test the performance of a cabinet dryer with a heating source derived from the wasted heat of an AC condenser, on drying red ginger, and with several different levels of drying load. Performance testing was carried out with 600, 900, and 1200 grams of red ginger, which were then divided into six drying racks. Data observations and analyzes include drying temperature, relative humidity, moisture content, drying rate, the heat used to increase material temperature, the heat used to evaporate material water, energy requirements for the drying process, and energy efficiency. The results show that the cabinet dryer with a heating source from the wasted heat of the AC condenser can dry the red ginger to reach a moisture content of 9.24-10.71\% following SNI standards, with a drying time of 6.5-8.7 hours. The energy used to dry red ginger ranges from 1281.67-2583.86 kJ. Drying efficiency achieves from each treatment ranges from 14.04-21.15\%.
\end{abstract}

Keywords: Cabinet dryer, Drying, Red ginger, Waste heat, Air conditioner condenser.

\begin{abstract}
ABSTRAK
Jahe merah kaya akan kandungan antioksidan dan bahan aktif, sehingga proses pengeringannya sebaiknya dilakukan dengan menggunakan suhu rendah. Pengeringan jahe merah pada suhu rendah dapat dilakukan dengan menggunakan cabinet dryer yang sumber pemanasnya berasal dari panas terbuang kondensor AC. Tujuan dari penelitian ini adalah untuk menguji kinerja cabinet dryer dengan sumber pemanas berasal dari panas terbuang kondensor $\mathrm{AC}$, pada pengeringan jahe merah, dan dengan beberapa tingkat beban pengeringan yang berbeda. Pengujian kinerja dilakukan dengan bahan jahe merah sebanyak 600, 900, dan 1200 gram yang kemudian dibagi ke dalam 6 buah rak pengering. Pengamatan dan analisis data meliputi suhu pengeringan, kelembaban udara, kadar air, laju pengeringan, panas yang digunakan untuk meningkatkan suhu bahan, panas yang digunakan untuk menguapkan air bahan, kebutuhan energi untuk proses pengeringan, serta efisiensi energi. Hasil penelitian menunjukkan bahwa cabinet dryer dengan sumber pemanas berasal dari panas terbuang kondensor AC mampu mengeringkan jahe merah hingga mencapai kadar air 9.24-10.71\% sesuai dengan standar SNI, dengan waktu pengeringan selama 6.5-8.7 jam. Energi yang terpakai untuk mengeringkan jahe merah berkisar antara 1281.67$2583.86 \mathrm{~kJ}$. Efisiensi pengeringan yang dicapai dari tiap perlakuan berkisar antara 14.04-21.15\%.
\end{abstract}

Kata Kunci: Cabinet dryer, Pengeringan, Jahe merah, Panas terbuang, Kondensor pendingin udara. 


\section{PENDAHULUAN}

Jahe merah (Zingiber officinale) merupakan sejenis tanaman rimpangrimpangan yang umumnya digunakan sebagai bumbu pelengkap masakan, bahan campuran dalam pembuatan makanan dan minuman, serta obat herbal. Merebaknya virus Covid-19 mendorong masyarakat untuk meningkatkan daya tahan tubuh agar senantiasa sehat, salah satunya adalah dengan cara mengonsumsi minuman herbal yang berbahan dasar jahe merah. Jahe merah diketahui memiliki aktivitas sebagai immunomodulator, terutama pada kandungan gingerol dan shogaol, yang bermanfaat untuk meningkatkan daya tahan tubuh (Putra, 2020).

Pengeringan merupakan salah satu cara untuk mengolah jahe merah menjadi minuman herbal instan atau jamu instan. Potongan jahe yang telah dikeringkan selanjutnya dapat dihaluskan dan diayak untuk mendapatkan serbuk jahe (Rifkowaty dkk., 2016). Produk serbuk jahe instan ini lebih mudah digunakan dan lebih tahan lama dalam penyimpanan karena memiliki kadar air yang rendah.

Kualitas jahe merah yang dikeringkan sangat bergantung pada proses pengeringan yang dilakukan. Jahe merah kaya akan kandungan antioksidan dan bahan aktif (Susanti dkk., 2015), sehingga proses pengeringannya sebaiknya dilakukan dengan menggunakan suhu rendah. Penggunaan suhu tinggi pada pengeringan jahe merah akan rentan merusak kandungan bahan aktif yang terkandung didalam jahe merah tersebut.

Pengeringan jahe merah pada suhu rendah dapat dilakukan dengan menggunakan cabinet dryer yang sumber pemanasnya berasal dari panas terbuang kondensor pendingin udara (AC). Panas yang berasal dari buangan kondensor AC ini biasanya tidak dimanfaatkan dan terlepas begitu saja ke lingkungan sekitarnya. Potensi panas keluaran kondensor $\mathrm{AC}$ ini dapat mencapai suhu sekitar $42.40-57.78^{\circ} \mathrm{C}$, yang diuji pada $\mathrm{AC}$ tipe split $0.5 \mathrm{hp}, 1 \mathrm{hp}$, dan jenis
AC sentral (Syam dkk., 2019; Rahmanto, 2011; Aziz dkk., 2015).

Kisaran suhu panas buangan kondensor $\mathrm{AC}$ tersebut sangat sesuai untuk pengeringan bahan-bahan pertanian yang menghindari penggunaan suhu tinggi. Pemanfaatan panas terbuang kondensor $\mathrm{AC}$ untuk pengeringan bahan-bahan pertanian juga terbilang aman dan telah diujicobakan pada beberapa penelitian terdahulu, seperti pada pengeringan anggur (Chandrasekar et al., 2018), asam gelugur (Mahlia et al., 2012), kunyit (Syam dkk., 2019), dan kentang (Rahmanto, 2011).

Jenis alat pengering tipe kabinet (cabinet dryer) dinilai sesuai secara konstruksi dan mekanisme kerjanya untuk dihubungkan pada kondensor AC guna memanfaatkan panas keluarannya. Akan tetapi, untuk mengetahui unjuk kerja cabinet dryer tersebut maka perlu dilakukan pengujian kinerja. Pengujian kinerja tersebut juga dilakukan sebagai bahan evaluasi untuk perbaikan rancangan cabinet dryer yang telah ada.

Syam dkk. (2019) telah melakukan penelitian pada cabinet dryer yang serupa dengan yang digunakan pada penelitian ini, namun dengan komoditas yang berbeda. Akan tetapi, kajian yang dilakukan hanya terfokus pada pengeringan bahan, dan belum membahas uji kinerja cabinet dryer tersebut secara keseluruhan, terutama untuk melihat unjuk kerjanya pada beberapa variasi massa sampel yang dikeringkan. Berdasarkan uraian-uraian tersebut diatas, maka dilakukan penelitian untuk menguji kinerja cabinet dryer dengan sumber pemanas berasal dari panas terbuang kondensor AC.

\section{Tujuan Penelitian}

Tujuan dari penelitian ini adalah untuk menguji kinerja cabinet dryer dengan sumber pemanas berasal dari panas terbuang kondensor AC, pada pengeringan jahe merah, dan dengan beberapa tingkat beban pengeringan yang berbeda. 


\section{METODOLOGI PENELITIAN}

Alat

Alat utama yang digunakan adalah cabinet dryer dengan sumber pemanas yang berasal dari panas terbuang kondensor $\mathrm{AC}$ (Gambar 1). AC yang digunakan adalah AC tipe split $0.5 \mathrm{hp}$ merk LG, dengan kapasitas pendinginan $5000 \mathrm{BTU} / \mathrm{h}$, dan kebutuhan daya listrik 390 watt.

Cabinet dryer yang digunakan pada penelitian ini memiliki dimensi $60 \mathrm{~cm} \times 59$ $\mathrm{cm} \times 124 \mathrm{~cm}$, dan dilengkapi dengan 6 buah rak pengering. Adapun peralatan pendukung yang digunakan dalam pengujian kinerja adalah termokopel, data logger, anemometer, hygrometer, stopwatch, oven, desikator, timbangan digital, tray, baskom, dan alat pengiris.

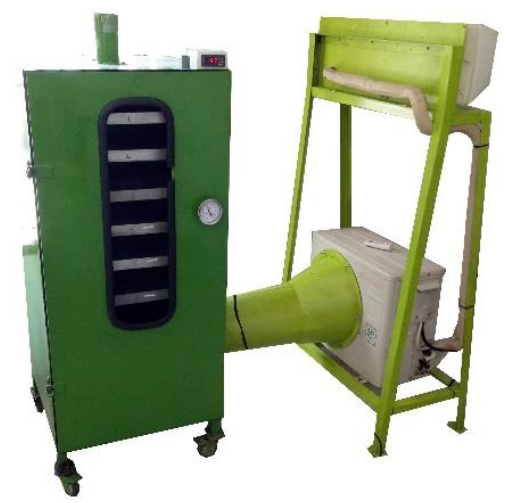

Gambar 1. Cabinet dryer dengan sumber pemanas berasal dari panas terbuang kondensor AC (Syam dkk., 2019)

\section{Bahan}

Bahan utama yang digunakan adalah jahe merah. Sedangkan bahan pendukung yang digunakan adalah silica gel dan plastik klip untuk pengemasan jahe merah yang telah dikeringkan.

\section{Prosedur Penelitian}

\section{a. Persiapan sampel jahe merah}

Bahan jahe merah terlebih dahulu dicuci hingga bersih, dan kemudian ditiriskan. Selanjutnya jahe merah disortasi untuk memilih bahan dengan karakter yang seragam. Setelah itu jahe merah diiris menggunakan alat pengiris dengan ketebalan $3 \mathrm{~mm}$. Selanjutnya hasil irisan jahe merah ditimbang sesuai dengan perlakuan pada penelitian. Langkah terakhir sampel irisan jahe merah dihamparkan pada masingmasing tray dan siap untuk dikeringkan.

Ada tiga perlakuan variasi massa sampel yang dikeringkan tiap rak, yaitu 100, 150, dan 200 gram. Setiap rak pada cabinet dryer diisi dengan massa bahan yang sama sesuai dengan perlakuan. Sehingga dengan jumlah rak pengering sebanyak 6 buah, maka total massa bahannya adalah 600, 900, dan 1200 gram. Variasi massa sampel tersebut bertujuan untuk melihat unjuk kerja pengeringan pada kerapatan ruang antar bahan dalam tray. Pada perlakuan massa 100 gram, sampel mengisi tray tanpa saling bertumpuk dan memiliki jarak antar bahan yang cukup renggang. Pada perlakuan massa 150 gram, sampel mengisi tray tanpa saling bertumpuk namun memiliki jarak antar bahan yang sangat rapat. Sedangkan pada perlakuan massa 200 gram, sampel mengisi tray dengan saling bertumpuk dan jarak antar bahannya sangat rapat.

\section{b. Proses pengeringan}

Sebelum sampel yang akan dikeringkan masuk ke dalam cabinet dryer, maka terlebih dahulu AC yang terhubung pada cabinet dryer dinyalakan hingga sensor suhu pada cabinet dryer mencapai angka $40^{\circ} \mathrm{C}$. Setelah cabinet dryer mencapai suhu yang diinginkan, maka sampel-sampel yang telah dihamparkan pada tray selanjutnya dimasukkan ke dalam cabinet dryer, dan mengisi posisi rak-rak pengering dengan nomor urutan 1-6. Rak nomor 1 adalah rak pengering dengan posisi paling atas, dan rak nomor 6 adalah rak pengering dengan posisi paling bawah.

Proses pengeringan dilakukan hingga sampel mencapai kadar air maksimal $12 \%$ (SNI 01-3393-1994). Penurunan massa sampel diukur setiap 1 jam. Proses pengeringan dilakukan sebanyak tiga kali ulangan untuk masing-masing perlakuan.

Selama proses pengeringan berlangsung, dilakukan pengukuran suhu dan kelembaban udara di dalam ruang pengering. Pengukuran suhu dilakukan dengan menggunakan termokopel, dan kelembaban udara diukur menggunakan hygrometer. Titik-titik 
pengukuran suhu mewakili posisi rak 1,2, 3, 4, 5, dan 6, plenum chamber, serta saluran udara panas dari kondensor menuju plenum chamber (Gambar 2).

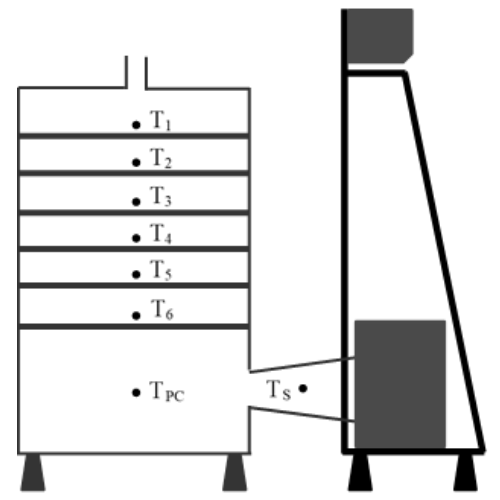

Gambar 2. Experimental setup

Pengukuran suhu pada ruang pengering juga dilakukan dalam kondisi cabinet dryer kosong tanpa beban pengeringan. Pengukuran suhu dilakukan setiap 10 menit. Pengukuran lainnya meliputi pengukuran kadar air awal dan akhir bahan, waktu pengeringan, dan laju aliran udara pengering.

\section{c. Perhitungan Parameter dan Analisis Data}

\section{Kadar air}

Pengukuran kadar air dilakukan dengan metode AOAC. Kadar air diukur sebelum dan sesudah proses pengeringan. Identifikasi kadar air selama proses pengeringan berlangsung dilakukan dengan cara menghitung rasio penurunan massa bahan terhadap massa kering bahan (Yadollahinia et al., 2008), dengan Persamaan (1) dan (2) sebagai berikut:

$$
\begin{aligned}
& M=\frac{w(t)-d}{w} \times 100 \% \\
& X=\frac{w(t)-d}{d}
\end{aligned}
$$

Dimana $\mathrm{M}$ adalah kadar air basis basah (\%), $\mathrm{X}$ adalah kadar air basis kering ( $\mathrm{g}_{\text {air }} / \mathrm{g}_{\text {bahan }}$ kering), d adalah massa bahan kering ( $\mathrm{g}$ ), $\mathrm{w}(\mathrm{t})$ adalah massa bahan pada waktu $\mathrm{t}$, dan $\mathrm{w}$ adalah massa bahan awal (g).

\section{Laju pengeringan}

Laju pengeringan ditentukan dengan cara menghitung selisih antara kadar air bahan selama pengeringan terhadap waktu
(Hossain et al., 2002). Laju pengeringan dihitung dengan Persamaan (3) sebagai berikut (Deshmukh et al., 2014; Akpinar et al., 2016):

$$
\frac{\mathrm{DR}}{\mathrm{dt}}=\frac{\mathrm{M}_{\mathrm{t}}-\mathrm{M}_{\mathrm{t}+\mathrm{dt}}}{\mathrm{t}}
$$

Dimana DR/dt adalah laju pengeringan

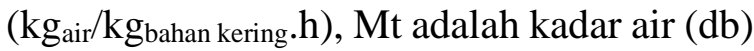
saat t, Mt+dt adalah kadar air (db) saat t+dt, dan $t$ adalah waktu pengeringan (h).

\section{Konsumsi energi listrik}

Energi listrik yang digunakan untuk operasional AC selama proses pengeringan dihitung dengan Persamaan (4) berikut:

$$
\mathrm{Q}_{\text {in }}=3.6 \times \mathrm{pk} \mathrm{x} \mathrm{t}
$$

Dimana $Q_{\text {in }}$ adalah energi listrik untuk operasional AC $(\mathrm{kJ})$, pk adalah daya listrik (watt), dan $\mathrm{t}$ adalah waktu pengeringan (h).

\section{Panas yang digunakan untuk meningkatkan suhu bahan}

Jumlah panas yang digunakan untuk meningkatkan suhu sampel jahe merah dihitung dengan Persamaan (5) sebagai berikut (Taib dkk., 1988; Sari dkk., 2014):

$$
\mathrm{Q}_{1}=\mathrm{m}_{\mathrm{o}} \times \mathrm{C}_{\mathrm{p}} \times\left(\mathrm{T}_{2}-\mathrm{T}_{1}\right)
$$

Nilai $\mathrm{C}_{\mathrm{p}}$ ditentukan dengan Persamaan Siebel (Heldman et al., 1981) berikut ini:

$$
\mathrm{C}_{\mathrm{p}}=0.837+0.034 \mathrm{M}_{\mathrm{o}}
$$

Dimana $\mathrm{Q}_{1}$ adalah panas yang digunakan untuk meningkatkan suhu bahan $(\mathrm{kJ}), \mathrm{m}_{\mathrm{o}}$ adalah massa awal bahan $(\mathrm{kg}), \mathrm{C}_{\mathrm{p}}$ adalah panas jenis bahan $\left(\mathrm{kJ} / \mathrm{kg}{ }^{\circ} \mathrm{C}\right), \mathrm{T}_{1}$ adalah suhu sampel sebelum dipanaskan $\left({ }^{\circ} \mathrm{C}\right), \mathrm{T}_{2}$ adalah suhu sampel setelah dipanaskan $\left({ }^{\circ} \mathrm{C}\right)$, dan $\mathrm{M}_{\mathrm{o}}$ adalah kadar air awal bahan (\% wb).

\section{Panas yang digunakan untuk menguapkan air bahan}

Jumlah panas yang digunakan untuk menguapkan air dari sampel jahe merah dihitung dengan Persamaan (7) sebagai berikut (Suhendar dkk., 2017):

$$
\mathrm{Q}_{2}=\mathrm{M}_{\mathrm{u}} \times \mathrm{H}_{\mathrm{fg}}
$$

Jumlah air yang harus diuapkan $\left(\mathrm{M}_{\mathrm{u}}\right)$ hingga bahan mencapai kadar air yang 
diinginkan, dihitung dengan Persamaan (8) sebagai berikut (Asmara dkk., 2010):

$$
\mathrm{M}_{\mathrm{u}}=\frac{\mathrm{W}_{\mathrm{o}}\left(\mathrm{M}_{\mathrm{o}}-\mathrm{M}_{\mathrm{f}}\right)}{\left(100-\mathrm{M}_{\mathrm{f}}\right)}
$$

Panas laten penguapan produk dihitung $\left(\mathrm{H}_{\mathrm{fg}}\right)$ dengan Persamaan (9) berikut (Putra dkk., 2014):

$$
\mathrm{H}_{\mathrm{fg}}=2502-(2.3775 \mathrm{~T})
$$

Dimana $\mathrm{Q}_{2}$ adalah panas yang digunakan untuk menguapkan air bahan $(\mathrm{kJ}), \mathrm{M}_{\mathrm{u}}$ adalah massa air yang harus diuapkan $(\mathrm{kg}), \mathrm{H}_{\mathrm{fg}}$ adalah panas laten penguapan produk $(\mathrm{kJ} / \mathrm{kg}), \quad \mathrm{W}_{\mathrm{o}}$ adalah massa awal bahan sebelum pengeringan $(\mathrm{kg}), \mathrm{M}_{\mathrm{o}}$ adalah kadar air awal (\% wb), $\mathrm{M}_{\mathrm{f}}$ adalah kadar air akhir (\% wb), dan $\mathrm{T}$ adalah suhu bahan $\left({ }^{\circ} \mathrm{C}\right)$.

\section{Kebutuhan energi untuk proses pengeringan}

Jumlah energi yang dibutuhkan selama proses pengeringan jahe merah dihitung dengan Persamaan (10) sebagai berikut (Taib dkk., 1988; Putra dkk., 2014):

$$
\mathrm{Q}_{\text {out }}=\mathrm{Q}_{1}+\mathrm{Q}_{2}
$$

Dimana Q out adalah energi untuk menaikkan suhu dan menguapkan air bahan $(\mathrm{kJ}), \mathrm{Q}_{1}$ adalah panas yang digunakan untuk meningkatkan suhu bahan $(\mathrm{kJ})$, dan $\mathrm{Q}_{2}$ adalah panas yang digunakan untuk menguapkan air bahan $(\mathrm{kJ})$.

\section{Efisiensi pengeringan}

Efisiensi pengeringan dihitung berdasarkan perbandingan antara jumlah kebutuhan energi selama proses pengeringan (Qout), dengan energi listrik untuk operasional AC selama proses pengeringan ( $Q_{\text {in }}$. Efisiensi pengeringan dihitung dengan Persamaan (11) sebagai berikut (Sari., 2017):

$$
\eta=\frac{Q_{\text {out }}}{Q_{\text {in }}} \times 100 \%
$$

Dimana $\eta$ adalah efisiensi pengeringan (\%), Qout adalah energi untuk menaikkan suhu dan menguapkan air bahan $(\mathrm{kJ})$, dan $\mathrm{Q}_{\text {in }}$ adalah energi listrik $(\mathrm{kJ})$.

\section{HASIL DAN PEMBAHASAN}

\section{a. Pengujian Tanpa Beban Pengeringan}

Pengujian tanpa beban pengeringan bertujuan untuk mengetahui kemampuan panas terbuang kondensor AC dalam mengisi ruang pengering. Pengujian tanpa pembebanan akan menunjukkan sebaran udara pengering dalam kondisi tanpa hambatan, sehingga dapat dibandingkan performanya ketika cabinet dryer diujikan dengan sampel pengeringan. Pengujian ini dilakukan selama 3 jam penuh.

Rata-rata suhu pada rak 1 adalah $36.01^{\circ} \mathrm{C}$, rak 2 adalah $36.41^{\circ} \mathrm{C}$, rak 3 adalah $36.59^{\circ} \mathrm{C}$, rak 4 adalah $36.94^{\circ} \mathrm{C}$, rak 5 adalah $37.85^{\circ} \mathrm{C}$, rak 6 adalah $38.37^{\circ} \mathrm{C}$, plenum chamber adalah $38.66^{\circ} \mathrm{C}$, dan saluran udara adalah $41.46^{\circ} \mathrm{C}$ (Gambar 3). Suhu rata-rata ini diukur ketika sensor pada cabinet dryer telah menunjukkan suhu optimal, yaitu $40^{\circ} \mathrm{C}$. Untuk mencapai suhu tersebut, dibutuhkan waktu \pm 45 menit dihitung sejak awal cabinet dryer dinyalakan.

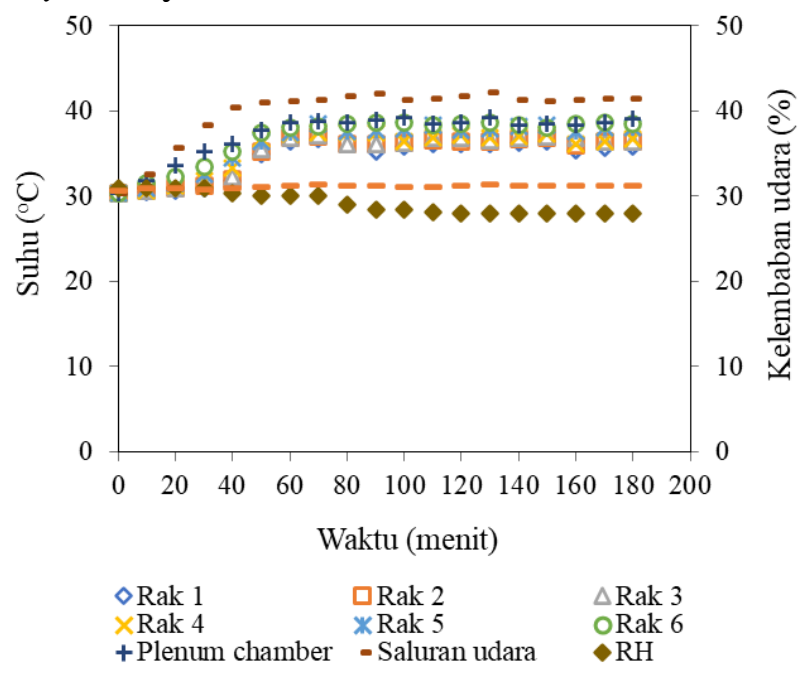

Gambar 3. Sebaran suhu cabinet dryer tanpa beban pengeringan

Dari Gambar 3 diketahui bahwa suhu antara rak pengering 1 hingga rak pengering 6 cenderung berbeda. Semakin dekat posisi rak pengering dengan plenum chamber, maka suhunya akan semakin tinggi, begitu juga sebaliknya. Hal ini disebabkan karena untuk menjangkau posisi rak terjauh, udara pengering dari plenum chamber memerlukan waktu yang lebih lama untuk melakukan perpindahan panas. 
Pergerakan udara panas ini sebenarnya sudah dibantu oleh dorongan yang dihasilkan oleh kipas pada kondensor. Akan tetapi karena adanya belokan dari saluran udara ke plenum chamber, maka kecepatan aliran udaranya menjadi berkurang. Hal ini juga ditambah lagi dengan posisi rak 1 yang terjauh dari plenum chamber, sehingga udara panas yang mengalir menuju rak 1 sebagian telah melakukan perpindahan panas dengan udara yang ada di rak-rak pengering sebelumnya.

Suhu lingkungan di sekitar cabinet dryer juga menjadi pengamatan yang dilakukan pada penelitian ini. Hal ini disebabkan karena suhu lingkungan berpengaruh pada suhu keluaran kondensor. Hal ini juga sesuai dengan hasil penelitian Rahmanto (2011) yang menyatakan bahwa semakin tinggi suhu lingkungan, maka suhu keluaran kondensor juga akan semakin tinggi, karena kenaikan suhu udara keluaran kondensor akan sama pada kecepatan aliran udara yang sama. Jika suhu lingkungan awal lebih tinggi maka suhu keluaran kondensornya juga akan lebih tinggi.

Kelembaban udara terendah yang dapat dicapai pada ruang pengering selama pengujian tanpa pembebanan adalah 28\%, dengan kelembaban udara awal adalah $31 \%$. Kelembaban udara ini menurun karena uap air yang terdapat pada ruang pengering telah diuapkan dan keluar meninggalkan ruang pengering. Setelah mencapai angka $28 \%$, selanjutnya kelembaban udara ini cenderung konstan.

\section{b. Suhu Pengeringan}

\section{Perlakuan 100 gram bahan tiap rak pengering}

Sebaran suhu pada cabinet dryer selama proses pengeringan berlangsung cenderung berbeda-beda untuk setiap perlakuan. Semakin banyak jumlah bahan yang dikeringkan, maka sebaran suhu udara pengeringnya semakin rendah. Untuk perlakuan 100 gram bahan tiap rak pengering, sebaran suhunya tidak terlalu jauh berbeda dengan sebaran suhu pada pengujian tanpa beban, dengan suhu rata-rata pada rak
1 adalah $35.48^{\circ} \mathrm{C}$, rak 2 adalah $35.82^{\circ} \mathrm{C}$, rak 3 adalah $36.02^{\circ} \mathrm{C}$, rak 4 adalah $36.30^{\circ} \mathrm{C}$, rak 5 adalah $37.25^{\circ} \mathrm{C}$, dan rak 6 adalah $37,79^{\circ} \mathrm{C}$. Sebaran suhu pada cabinet dryer untuk perlakuan 100 gram bahan tiap rak pengering ditampilkan pada Gambar 4.

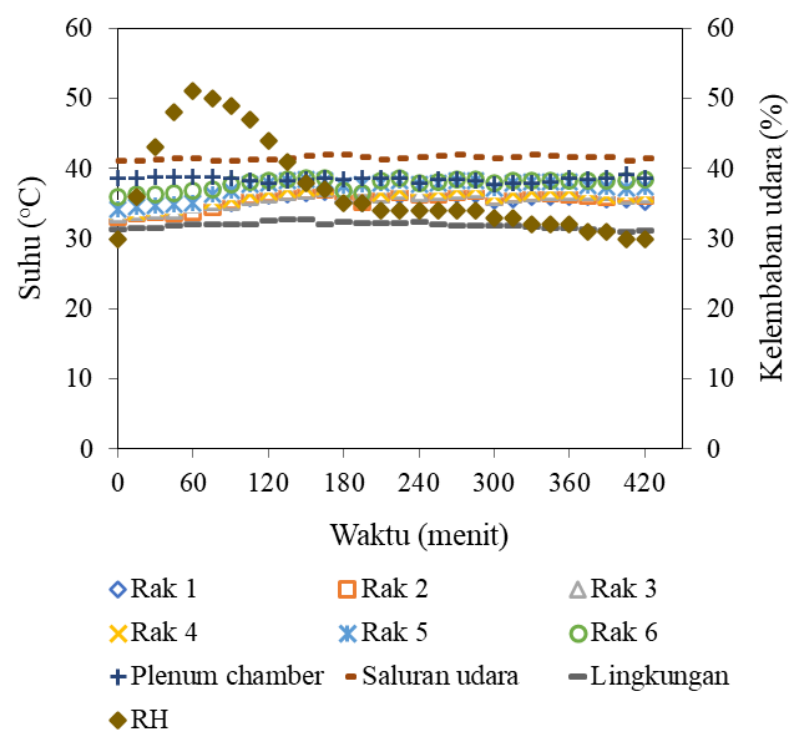

Gambar 4. Sebaran suhu pengeringan untuk perlakuan 100 gram bahan tiap rak

Dari Gambar 4 diketahui bahwa sebaran suhunya cenderung tidak terlalu jauh berbeda dengan sebaran suhu pada pengujian tanpa beban. Hal ini disebabkan karena pada perlakuan 100 gram bahan tiap rak pengering masih memiliki jarak yang renggang antara bahan yang dihamparkan pada tray. Jarak antar bahan ini membuat aliran udara panasnya tidak terlalu terhalangi dan lebih leluasa bergerak dari plenum chamber menuju rak 6 sampai dengan rak 1. Rata-rata suhu udara pengeringnya menjadi lebih rendah sedikit dibandingkan dengan suhu pada pengujian tanpa beban karena udara pengering yang mengalir dalam perjalanannya juga melakukan perpindahan panas dengan bahan pada tiap rak, sehingga suhu pada tiap raknya menjadi lebih rendah.

Kelembaban udara pada perlakuan ini cenderung meningkat di 60 menit pertama, yang semula $30 \%$ meningkat hingga mencapai $51 \%$, kemudian konstan selama beberapa menit, dan akhirnya kembali turun hingga pengeringan berakhir. Peningkatan kelembaban udara di awal pengeringan ini disebabkan karena menguapnya air dari 
dalam bahan, dimana pada awal pengeringan air bebas lebih cepat dan lebih banyak menguap. Air yang menguap ini mengisi ruang pengering dan kemudian meningkatkan kelembaban udara.

Akan tetapi, semakin lama proses pengeringan berlangsung maka jumlah uap air tersebut akan berkurang karena terbawa keluar melalui saluran pembuangan uap air. Setelah sebagian besar air bebas diuapkan, maka laju penguapan air dari dalam bahanpun menurun karena hanya tersisa air terikat yang sulit untuk diuapkan. Pada fase ini kelembaban udara juga akan terus menurun karena jumlah uap air di dalam ruang pengering juga sudah semakin berkurang.

\section{Perlakuan 150 gram bahan tiap rak pengering}

Sebaran suhu pengeringan pada perlakuan 150 gram bahan tiap rak ditampilkan pada Gambar 5. Rata-rata suhu tiap rak pada perlakuan ini lebih rendah 0.48 $0.8^{\circ} \mathrm{C}$ jika dibandingkan dengan perlakuan 100 gram bahan tiap rak pengering, dan lebih rendah $1.06-1.41^{\circ} \mathrm{C}$ jika dibandingkan dengan pengujian tanpa pembebanan, dimana suhu pada rak 1 adalah $34.76^{\circ} \mathrm{C}$, rak 2 adalah $35.01^{\circ} \mathrm{C}$, rak 3 adalah $35.22^{\circ} \mathrm{C}$, rak 4 adalah $35.66^{\circ} \mathrm{C}$, rak 5 adalah $36.44^{\circ} \mathrm{C}$, dan rak 6 adalah $37.31{ }^{\circ} \mathrm{C}$. Hal ini disebabkan karena pada perlakuan ini hampir tidak ada jarak antar bahan yang dihamparkan pada tray. Bahan yang disusun di atas tray menutupi hampir semua permukaan tray, sehingga aliran udara pengeringnya menjadi terhambat. Udara pengering yang bergerak melaluinya akan melakukan perpindahan panas dengan bahan terlebih dahulu, sehingga udara pengering yang sampai pada rak berikutnya telah kehilangan sebagian kalor yang dimiliki.

Kelembaban udara pada perlakuan ini meningkat di 60 menit pertama, kemudian konstan selama \pm 30 menit, dan akhirnya turun hingga proses pengeringan selesai. Jika dibandingkan dengan perlakuan sebelumnya, peningkatan kelembaban udara pada perlakuan ini jauh lebih tinggi, yaitu mencapai $67 \%$. Hal ini disebabkan karena jumlah bahan yang dikeringkan pada perlakuan ini lebih banyak, sehingga ada lebih banyak juga air yang diuapkan.

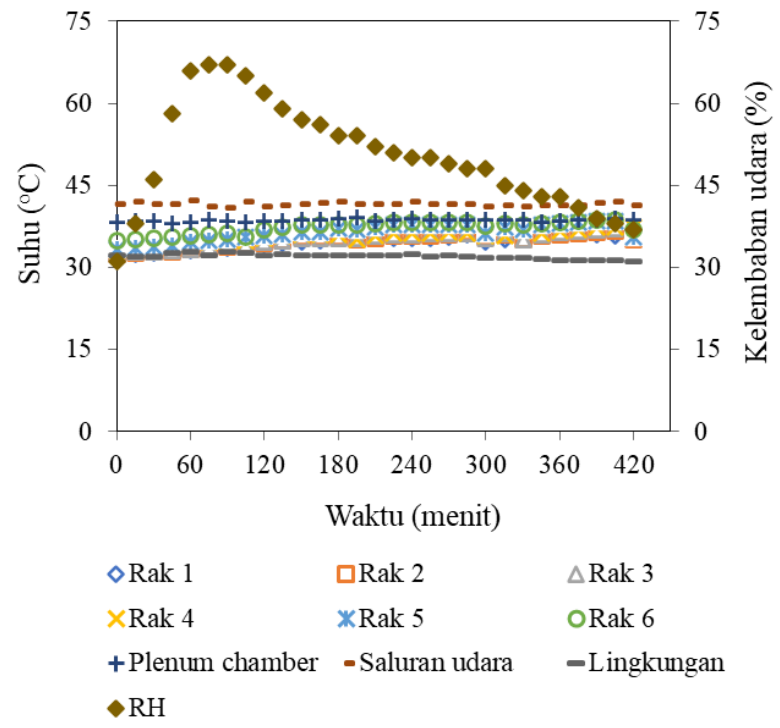

Gambar 5. Sebaran suhu pengeringan untuk perlakuan 150 gram bahan tiap rak

\section{Perlakuan 200 gram bahan tiap rak pengering}

Sama seperti dua perlakuan sebelumnya, sebaran suhu pada perlakuan 200 gram bahan tiap rak pengering juga mengalami penurunan dibandingkan dengan perlakuan tanpa pembebanan. Penurunan suhu ruang pengering pada perlakuan ini adalah yang terbanyak jika dibandingkan dengan dua perlakuan sebelumnya. Rata-rata suhu pada rak 1 adalah $33.63^{\circ} \mathrm{C}$, rak 2 adalah $34.01^{\circ} \mathrm{C}$, rak 3 adalah $34.72^{\circ} \mathrm{C}$, rak 4 adalah $34.88^{\circ} \mathrm{C}$, rak 5 adalah $35.06^{\circ} \mathrm{C}$, dan rak 6 adalah $36.02^{\circ} \mathrm{C}$, seperti ditampilkan pada Gambar 6 .

Sebaran suhu pada perlakuan ini menjadi yang terendah dibandingkan dengan dua perlakuan sebelumnya. Hal ini disebabkan karena pada perlakuan ini selain hampir tidak ada jarak antar bahan yang disusun diatas tray, jumlah bahan yang dikeringkan juga adalah yang terbanyak dibandingkan dengan dua perlakuan sebelumnya. Pada perlakuan ini bahan yang disusun pada tray saling bertumpuk, dan semakin menghambat udara pengering yang akan melaluinya. Akibatnya, proses kontak antara bahan dan udara pengering menjadi semakin lama, dan panas yang berpindah ke bahan akan semakin banyak, sehingga 
menyisakan suhu yang lebih rendah yang mengalir ke rak pengering diatasnya.

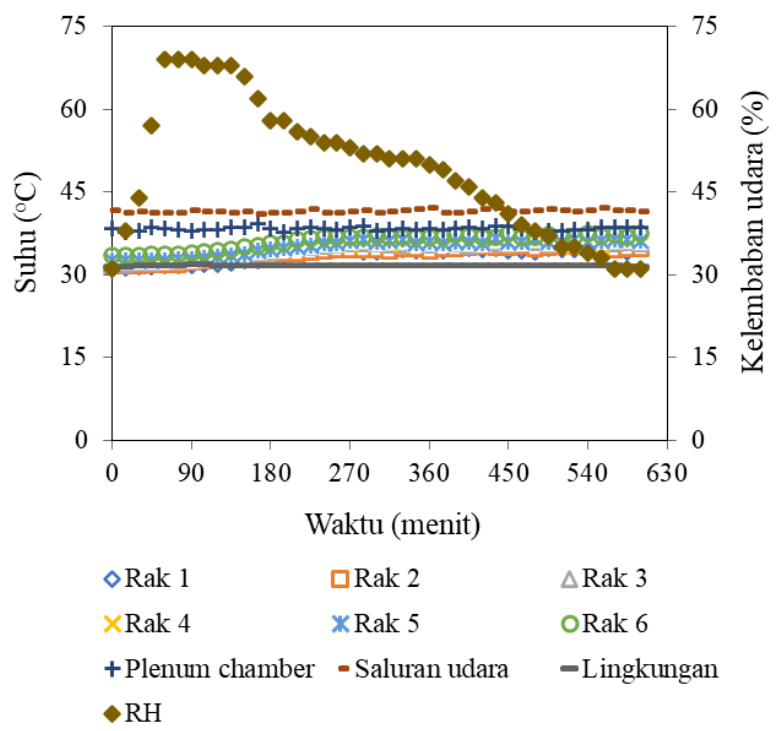

Gambar 6. Sebaran suhu pengeringan untuk perlakuan 200 gram bahan tiap rak

Untuk suhu plenum chamber dan saluran udara pengering dari kondensor cenderung sama pada ketiga perlakuan dan juga pada pengujian tanpa pembebanan. Rata-rata suhu plenum chamber dan saluran udara pengering untuk ketiga perlakuan masing-masing berkisar antara $38.35-38.60^{\circ} \mathrm{C}$ dan $41.52-$ $41.58^{\circ} \mathrm{C}$. Suhu plenum chamber dan saluran udara ini tidak dipengaruhi oleh jumlah bahan yang dikeringkan, akan tetapi dipengaruhi oleh suhu lingkungan di sekitar cabinet dryer seperti yang telah diuraikan pada bahasan pengujian tanpa pembebanan.

Peningkatan kelembaban udara pada perlakuan ini adalah yang tertinggi dibandingkan dengan dua perlakuan sebelumnya. Pada perlakuan ini kelembaban udara di 60 menit pertama dapat meningkat hingga $69 \%$, dan bertahan sekitar \pm 75 menit, untuk selanjutnya kembali mengalami penurunan hingga proses pengeringan berakhir. Hal ini disebabkan karena pada perlakuan ini massa bahan yang dikeringkan adalah yang terbanyak dibandingkan dengan dua perlakuan sebelumnya, sehingga jumlah air bebas yang diuapkan diawal pengeringan juga menjadi lebih banyak. Jika dibandingkan antara ketiga perlakuan yang ada, kelembaban udara selama proses pengeringan memiliki pola pergerakan yang sama. Yang menjadi pembeda adalah tingkat persentase kenaikan kelembaban udara, serta persentase kelembaban udara di akhir pengeringan untuk setiap perlakuan.

\section{c. Penurunan Kadar Air}

Pada umumnya kadar air akhir jahe merah kering untuk semua perlakuan telah memenuhi standar SNI, yaitu maksimal $12 \%$. Kadar air awal bahan adalah sebesar $88.40 \%$. Rata-rata kadar air akhir untuk perlakuan massa bahan 100 gram tiap rak adalah 9.64\%, perlakuan massa bahan 150 gram tiap rak adalah $10.71 \%$, dan perlakuan massa bahan 200 gram tiap rak adalah $9.24 \%$.

Hasil penelitian juga menunjukkan bahwa semakin banyak jumlah massa bahan yang dikeringkan, maka akan semakin lama bahan tersebut mencapai kadar air maksimal $12 \%$, seperti yang terjadi pada perlakuan 200 gram bahan tiap rak pengering. Hal ini disebabkan karena jumlah bahan yang lebih banyak memiliki jumlah air yang lebih banyak juga untuk diuapkan. Penurunan kadar air selama proses pengeringan ditampilkan pada Gambar 7, 8, dan 9.

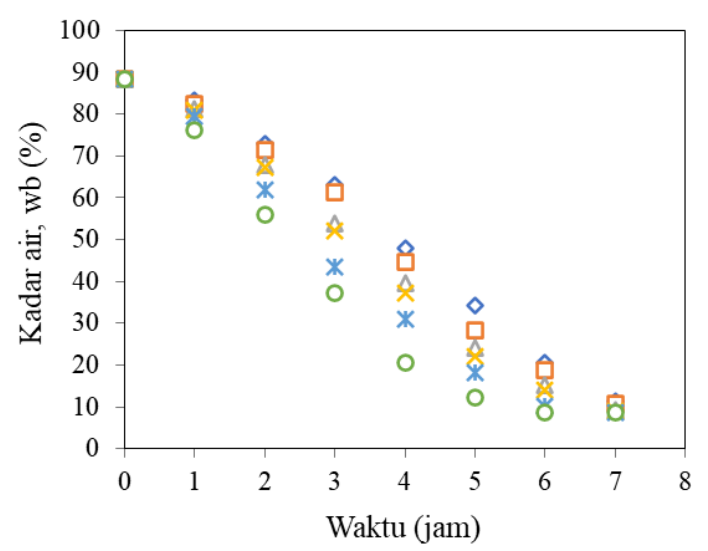

$\diamond$ Rak $1 \square$ Rak $2 \triangle$ Rak $3 \times$ Rak $4 \times$ Rak 5 oRak 6

Gambar 7. Penurunan kadar air untuk perlakuan 100 gram bahan tiap rak 


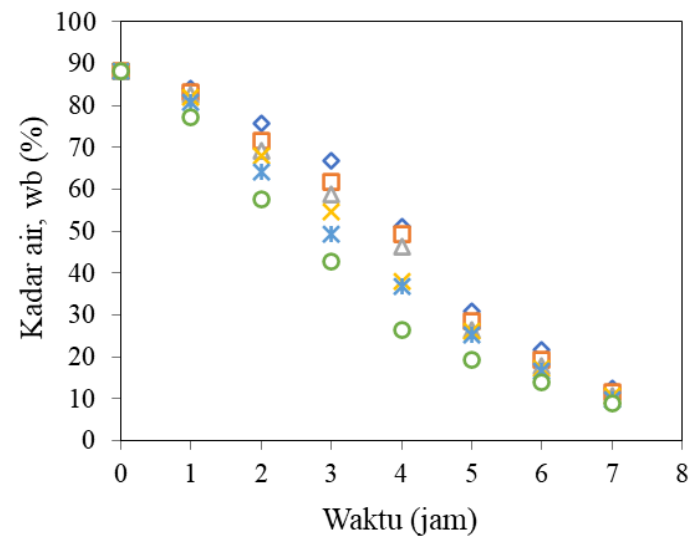

$\diamond \operatorname{Rak} 1 \quad \square \operatorname{Rak} 2 \triangle \operatorname{Rak} 3 \times \operatorname{Rak} 4$ *Rak 5 oRak 6

Gambar 8. Penurunan kadar air untuk perlakuan 150 gram bahan tiap rak

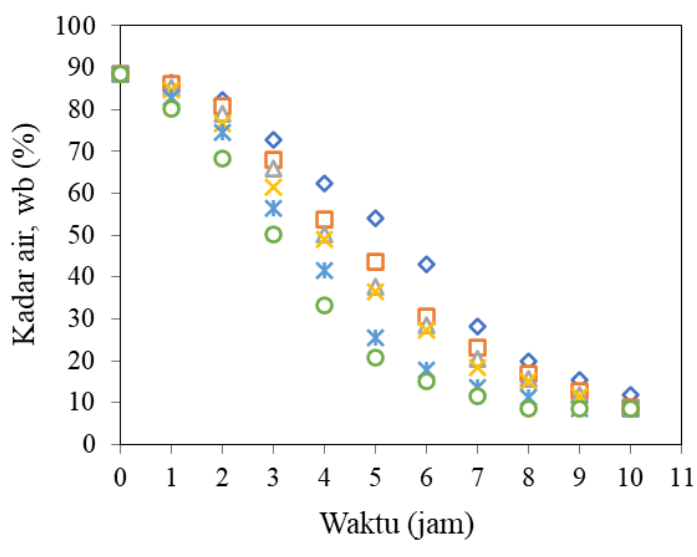

$\diamond$ Rak $1 \quad \square \operatorname{Rak} 2 \quad \Delta \operatorname{Rak} 3 \times \operatorname{Rak} 4 \quad$ Rak 5 oRak 6

Gambar 9. Penurunan kadar air untuk perlakuan 200 gram bahan tiap rak

Penurunan kadar air terendah untuk semua perlakuan selalu terdapat pada rak 6 . Hal ini disebabkan karena bahan yang terletak pada rak 6 lebih dekat posisinya dengan plenum chamber, sehingga suhu bahannya lebih tinggi jika dibandingkan dengan rak-rak yang berada di atasnya. Semakin tinggi suhu yang diterima oleh bahan, maka akan semakin tinggi pula penguapan air bahan sehingga kadar airnya pun menurun (Zamharir dkk., 2016).

Selain itu, semakin tinggi suhu udara pengering maka energi panas yang dibawa oleh udara pengering tersebut juga akan semakin besar, sehingga jumlah massa air yang diuapkan akan semakin banyak. Hasil ini juga diperkuat oleh Taib et al. (1988), yang menyatakan bahwa kemampuan bahan untuk melepaskan air dari permukaan bahan akan meningkat dengan semakin meningkatnya suhu udara pengering, sehingga kadar air bahan menjadi semakin rendah.

\section{d. Analisis Efisiensi}

\section{Lama pengeringan}

Untuk mencapai kadar air jahe merah kering maksimal $12 \%$, rata-rata waktu pengeringannya adalah selama 6.5 jam untuk perlakuan 100 gram bahan tiap rak pengering, 7 jam untuk perlakuan 150 gram bahan tiap rak pengering, dan 8.7 jam untuk untuk perlakuan 200 gram bahan tiap rak pengering. Semakin banyak massa bahan yang dikeringkan, maka semakin lama juga waktu yang dibutuhkan untuk menguapkan air dari dalam bahan.

Jika ditinjau dari posisi rak pengering, maka masing-masing rak pengering memiliki waktu pengeringan yang berbeda-beda. Bahan pada rak 6 umumnya mencapai kadar air $\pm 12 \%$ terlebih dahulu dibandingkan dengan bahan pada rak-rak pengering lainnya, karena bahan pada rak 6 diuntungkan secara posisi yang berdekatan dengan sumber udara panas, sehingga penguapan airnya lebih cepat. Waktu pengeringan yang dibutuhkan bahan pada rak 6 untuk perlakuan 100 gram jahe merah per rak adalah 5 jam, sedangkan untuk perlakuan 150 gram dan 200 gram jahe merah per rak 7 jam. Hal ini berbanding terbalik dengan rak 1, yang merupakan rak pengering dengan posisi terjauh dari sumber udara panas. Waktu pengeringan yang dibutuhkan bahan pada rak 1 untuk perlakuan 100 gram bahan tiap rak adalah 7 jam, untuk perlakuan 150 gram bahan per rak adalah 7 jam, dan untuk perlakuan 100 gram bahan per rak adalah 10 jam.

Dengan kata lain, semakin dekat posisi rak pengering dengan sumber udara panas, maka akan semakin cepat juga waktu pengeringannya. Sehingga agar waktu pengeringan bahan tiap rak menjadi lebih seragam, maka perlu dilakukan rotasi rak pengering per satuan waktu tertentu. Misalnya rotasi rak pengering dari posisi rak 1 berpindah ke posisi rak 2, posisi rak 2 
berpindah ke posisi rak 3, dan seterusnya, yang bisa dilakukan setiap jeda waktu tertentu. Dengan merotasikan rak pengering, maka bahan pada tiap rak memiliki kesempatan yang sama untuk menerima potensi suhu udara pengering pada masingmasing tingkatan rak, sehingga waktu pengeringan bahan untuk setiap rak akan menjadi lebih seragam. Cara ini juga sudah terbukti, salah satunya pada hasil penelitian yang dilakukan oleh Triwahyudi (2009) yang melakukan pengeringan kapulaga dengan alat pengering efek rumah kaca hybrid tipe rak berputar secara vertikal, dengan hasil suhu pengeringan dan kadar air yang lebih seragam.

\section{Laju pengeringan}

Laju pengeringan merupakan banyaknya jumlah air yang menguap per satuan waktu. Hasil penelitian menunjukkan bahwa laju pengeringan tertinggi terjadi di awal proses pengeringan, dan kemudian semakin menurun dengan bertambahnya waktu (Gambar 10, 11, dan 12). Fenomena tersebut terjadi untuk semua perlakuan pada penelitian ini.

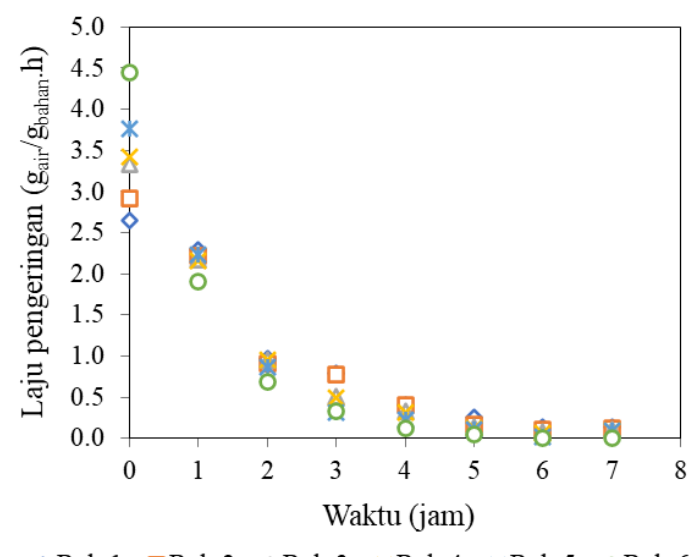

$\diamond$ Rak $1 \quad \square \operatorname{Rak} 2 \triangle \operatorname{Rak} 3 \times \operatorname{Rak} 4$ *Rak 5 oRak 6

Gambar 10. Laju pengeringan untuk perlakuan 100 gram bahan tiap rak

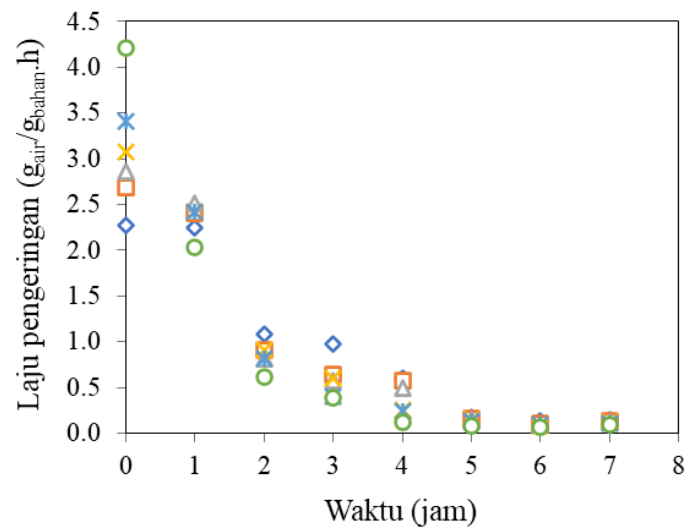

$\diamond$ Rak $1 \quad \square \operatorname{Rak} 2 \quad \Delta \operatorname{Rak} 3 \quad \times \operatorname{Rak} 4 \quad$ Rak 5 oRak 6

Gambar 11. Laju pengeringan untuk perlakuan 150 gram bahan tiap rak

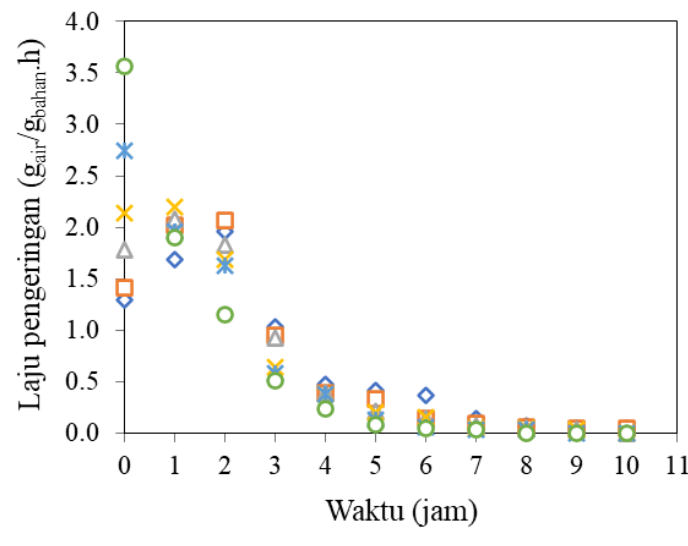

$\diamond \operatorname{Rak} 1 \quad \square \operatorname{Rak} 2 \quad \triangle \operatorname{Rak} 3 \times \operatorname{Rak} 4 \quad$ Rak $5 \quad$ oRak 6

Gambar 12. Laju pengeringan untuk perlakuan 200 gram bahan tiap rak

Untuk bahan yang dikeringkan hingga penurunan massanya konstan, maka laju pengeringan saat massanya konstan adalah 0 , seperti yang terjadi pada bahan di rak 6 untuk semua perlakuan. Ini berarti bahwa tidak ada lagi air yang menguap dari dalam bahan. Fenomena ini disebabkan karena diawal pengeringan air bebas pada bahan masih mudah untuk menguap. Semakin lama proses pengeringan berlangsung, maka air bebas tersebutpun habis, dan menyisakan air terikat yang sulit untuk berdifusi ke permukaan bahan. Kandungan air bebas tersebut mudah untuk menguap karena ia berada dalam fase cair yang mengisi rongga sel dan ruang antar sel. Sementara air terikat lebih sulit dihilangkan karena melekat secara higroskopis ke dinding sel (Misha et al., 2013). 
Kecepatan laju pengeringan dapat dipengaruhi juga oleh faktor eksternal seperti suhu, kelembaban udara, dan kecepatan aliran udara pada ruang pengering (Rozana $e t$ al., 2016). Dari hasil penelitian diketahui bahwa laju pengeringan bahan pada rak 6 selalu lebih tinggi jika dibandingkan dengan bahan pada rak-rak lainnya, dan laju pengeringan terendah adalah pada rak 1 . Hal ini disebabkan karena bahan pada rak 6 menerima suhu yang lebih tinggi dibandingkan dengan rak-rak lainnya untuk semua perlakuan, seperti yang telah diuraikan pada bagian suhu pengeringan.

Demikian juga halnya dengan kelembaban dan kecepatan aliran udara. Karena posisinya yang berdekatan dengan plenum chamber maka rak 6 menerima suhu dan kecepatan aliran udara yang lebih tinggi, dan dengan demikian kelembaban udaranya akan menjadi lebih rendah dari rak-rak yang lainnya. Kelembaban udara tersebut berpengaruh terhadap proses pemindahan uap air. Apabila kelembaban udara rendah, maka perbedaan tekanan uap di dalam dan di luar bahan menjadi besar, sehingga mempermudah pemindahan uap air dari dalam menuju luar bahan (Kemp, 2007).

\section{Energi yang dibutuhkan untuk proses pengeringan}

Energi input yang dibutuhkan untuk proses pengeringan berasal dari energi listrik. Energi listrik ini digunakan untuk mengoperasikan AC agar dapat menghasilkan kerja kondensor, dan kemudian kondensor menghasilkan panas terbuang yang selanjutnya disalurkan ke dalam ruang pengering. Besarnya jumlah energi listrik yang dibutuhkan untuk proses pengeringan ditampilkan pada Tabel 1 sebagai berikut.

Tabel 1. Energi listrik yang dibutuhkan selama proses pengeringan

\begin{tabular}{cc}
\hline $\begin{array}{c}\text { Perlakuan massa bahan } \\
\text { tiap rak (gram) }\end{array}$ & $\begin{array}{c}\text { Energi listrik yang } \\
\text { dibutuhkan }(\mathrm{kJ})\end{array}$ \\
\hline 100 & 9126 \\
150 & 9828 \\
200 & 12214.8 \\
\hline
\end{tabular}

Dari Tabel 1 diketahui bahwa semakin banyak jumlah bahan yang dikeringkan, maka akan semakin tinggi kebutuhan energi listrik pengeringannya. Hal ini disebabkan karena semakin banyak jumlah bahan yang dikeringkan, maka akan semakin lama waktu pengeringan yang butuhkan agar bahan mencapai kadar air maksimal 12\%. Selain daya listrik, besarnya energi listrik yang digunakan selama proses pengeringan ini juga sangat tergantung pada waktu pengeringan. Pada daya listrik yang sama, semakin lama proses pengeringan, maka energi listrik yang dibutuhkan akan semakin besar, dan begitu juga sebaliknya.

\section{Energi yang terpakai untuk mengeringkan bahan}

Besarnya energi yang terpakai untuk pengeringan jahe merah merupakan jumlah energi yang diperlukan untuk memanaskan bahan ditambah energi yang diperlukan untuk menguapkan air bahan. Besarnya energi yang terpakai untuk mengeringkan jahe merah ditampilkan pada Tabel 2, sedangkan parameter pendukung untuk menghitung energi yang terpakai dalam pengeringan jahe merah tersebut ditampilkan pada Tabel 3 .

Tabel 2. Jumlah energi yang terpakai untuk mengeringkan bahan

\begin{tabular}{cccc}
\hline $\begin{array}{c}\text { Perlakuan } \\
\text { bahan } \\
\text { tiap rak } \\
\text { gram })\end{array}$ & $\begin{array}{c}\text { Energi untuk } \\
\text { memanaskan } \\
\text { bahan, } Q_{1} \\
(\mathrm{~kJ})\end{array}$ & $\begin{array}{c}\text { Energi } \\
\text { untuk } \\
\text { menguapkan } \\
\text { air, } \mathrm{Q}_{2}(\mathrm{~kJ})\end{array}$ & $\begin{array}{c}\text { Energi } \\
\text { yang } \\
\text { terpakai, } \\
\mathrm{Q}_{\text {out }}(\mathrm{kJ})\end{array}$ \\
\hline 100 & 25.69 & 1255.99 & 1281.67 \\
150 & 36.09 & 1885.29 & 1921.38 \\
200 & 43.43 & 2540.43 & 2583.86 \\
\hline
\end{tabular}

Tabel 3. Nilai panas jenis bahan, panas laten penguapan produk, dan jumlah massa air bahan yang harus diuapkan

\begin{tabular}{cccc}
\hline $\begin{array}{c}\text { Perlakuan } \\
\text { massa tiap } \\
\text { rak (gram) }\end{array}$ & $\begin{array}{c}\text { Panas jenis } \\
\text { bahan, } \mathrm{C}_{\mathrm{p}} \\
\left(\mathrm{kJ} / \mathrm{kg}{ }^{\circ} \mathrm{C}\right)\end{array}$ & $\begin{array}{c}\text { Air yang } \\
\text { diuapkan, } \\
\mathrm{M}_{\mathrm{u}}(\mathrm{kg})\end{array}$ & $\begin{array}{c}\text { Panas laten } \\
\text { penguapan, } \\
\mathrm{H}_{\mathrm{gf}}(\mathrm{kJ} / \mathrm{kg})\end{array}$ \\
\hline 100 & 3.8426 & 0.52 & 2415.36 \\
150 & 3.8426 & 0.78 & 2417.04 \\
200 & 3.8426 & 1.05 & 2419.46 \\
\hline
\end{tabular}


Dari Tabel 2 diketahui bahwa semakin banyak jumlah bahan yang dikeringkan, maka akan semakin besar energi yang dibutuhkan untuk mengeringkan bahan. Hal ini disebabkan karena bahan dengan jumlah yang lebih besar memerlukan waktu pengeringan yang lebih lama. Energi yang dibutuhkan untuk pengeringan bahan juga berkaitan dengan massa awal bahan, dimana semakin besar massa bahan yang akan dikeringkan, maka akan semakin besar juga jumlah air yang harus diuapkan dari dalam bahan tersebut. Dengan demikian penggunaan energi untuk pengeringannyapun akan menjadi lebih besar.

\section{Efisiensi pengeringan}

Efisiensi pengeringan untuk masingmasing perlakuan ditampilkan pada Tabel 4 . Dari Tabel 4 diketahui bahwa semakin banyak jumlah bahan yang dikeringkan, maka akan semakin tinggi efisiensi pengeringannya, begitu juga sebaliknya. Efisiensi pengeringan pada pengujian ini tergolong rendah. Hal ini disebabkan karena untuk input energi yang tinggi (9126$12214.8 \mathrm{~kJ}$ ), jumlah bahan yang dikeringkan terlalu sedikit (600-1200 gram). Dengan demikian masih memungkinkan untuk menambah jumlah bahan yang dikeringkan. Akan tetapi hal ini akan berpengaruh pada lama waktu pengeringannya. Nilai efisiensi pengeringan yang rendah ini juga berarti bahwa energi input yang masuk ke dalam sistem pengering belum digunakan secara maksimal untuk proses pengeringan (Sari, 2019).

Tabel 4. Efisiensi pengeringan

\begin{tabular}{cc}
\hline $\begin{array}{c}\text { Perlakuan massa bahan } \\
\text { tiap rak (gram) }\end{array}$ & $\begin{array}{c}\text { Efisiensi pengeringan } \\
(\%)\end{array}$ \\
\hline 100 & 14.04 \\
150 & 19.55 \\
200 & 21.15 \\
\hline
\end{tabular}

Hal yang dapat dilakukan untuk meningkatkan efisiensi pengeringan adalah dengan memodifikasi ruang pengering dan menambahkan jumlah rak pengering, yang semula berjumlah 6 buah rak, dapat ditingkatkan menjadi 7-10 rak. Hal ini masih memungkinkan mengingat jarak antar rak pengering masih cukup renggang dan memungkinkan untuk adanya penambahan jumlah rak. Selain itu, input energi untuk pengeringan juga sangat besar sehingga masih memungkinkan untuk meningkatkan kapasitas pengeringan.

Langkah lain yang bisa dilakukan untuk meningkatkan efisiensi pengeringan adalah dengan melakukan rotasi rak selama pengeringan, sehingga masing-masing rak tidak berada pada posisi yang sama dari awal pengeringan hingga akhir pengeringan. Hal ini berpotensi untuk meningkatkan efisiensi pengeringan karena dengan merotasikan rak pengering maka suhu yang diterima oleh bahan akan lebih seragam. Seperti telah dijelaskan pada bagian sebaran suhu udara pengering, diketahui bahwa cabinet dryer memiliki suhu yang berbeda-beda pada masing-masing rak.

Dengan merotasikan rak pengering maka rak dengan posisi terjauh dari plenum chamber akan dapat menerima suhu yang lebih tinggi ketika dirotasikan, dan laju pengeringannyapun akan lebih seragam. Dengan demikian, maka waktu pengeringannya akan menjadi lebih singkat, sehingga meningkatkan efisiensi pengeringan.

\section{KESIMPULAN}

Dari pengujian kinerja yang telah dilakukan maka diperoleh kesimpulan sebagai berikut:

1. Rata-rata sebaran suhu ruang pengering pada cabinet dryer dalam kondisi kosong tanpa beban pengeringan pada rak 1 adalah $36.01^{\circ} \mathrm{C}$, rak 2 adalah $36.411^{\circ} \mathrm{C}$, rak 3 adalah $36.59^{\circ} \mathrm{C}$, rak 4 adalah $36.94^{\circ} \mathrm{C}$, rak 5 adalah $37.85^{\circ} \mathrm{C}$, rak 6 adalah $38.37^{\circ} \mathrm{C}$, plenum chamber adalah $38.66^{\circ} \mathrm{C}$, dan saluran udara dari kondensor adalah $41.46^{\circ} \mathrm{C}$. Suhu ini akan menurun saat pengujian dengan bahan.

2. Cabinet dryer dengan memanfaatkan panas terbuang kondensor AC dapat mengeringkan bahan jahe merah sebanyak 600 gram (100 gram tiap rak) selama 6.5 
jam dengan kadar air akhir sebesar 9.64\%, 900 gram (150 gram tiap rak) selama 7 jam dengan kadar air akhir sebesar $10.71 \%$, dan 1200 gram (200 gram tiap rak) selama 8.7 jam dengan kadar air akhir sebesar $9.24 \%$.

3. Energi yang terpakai untuk mengeringkan jahe merah sebanyak 600 gram (100 gram tiap rak) adalah $1281.67 \mathrm{~kJ}$, jahe merah sebanyak 900 gram (150 gram tiap rak) adalah $1921.38 \mathrm{~kJ}$, dan jahe merah sebanyak 1200 gram (200 gram tiap rak) adalah $2583.86 \mathrm{~kJ}$.

4. Efisiensi pengeringan untuk perlakuan jahe merah sebanyak 600 gram (100 gram tiap rak) adalah $14.04 \%$, jahe merah sebanyak 900 gram (150 gram tiap rak) adalah $19.55 \%$, dan jahe merah sebanyak 1200 gram (200 gram tiap rak) adalah $21.15 \%$.

\section{DAFTAR PUSTAKA}

Akpinar, E. K., and Toraman, S. 2016. Determination of drying kinetics and convective heat transfer coefficients of ginger slices. Heat and Mass Transfer. 52(10): 2271-2281.

Asmara, S., dan Warji. 2010. Kinerja pengeringan chip ubi kayu. Jurnal Keteknikan Pertanian. 24(2): 75-80.

Aziz, A., Harianto, J., dan Mainil, A. K. 2015. Potensi pemanfaatan energi panas terbuang pada kondensor AC sentral untuk pemanas air hemat energi. Jurnal Mekanikal. 6(2): 569576.

Chandrasekar, M., Senthilkumar, T., Kumaragurubaran, B., and Fernandes, J. P. 2018. Experimental investigation on a solar dryer integrated with condenser unit of split air conditioner (A/C) for enhancing drying rate. Renewable Energy. 122: 375-381.

Deshmukh, A. W., Varma, M. N., Yoo, C. K., and Wasewar, K. L. 2014. Investigation of Solar drying of ginger (Zingiber officinale): Emprical modelling, drying characteristics, and quality study. Chinese Journal of Engineering. 2014: 1-7.

Heldman, D. R., and Singh, R. P. 1981. Food Process Engineering, The AVI Pub. Co. Inc., Westport, Connecticut.

Hossain, M. A., and Bala, B. K. 2002. Thin layer drying characteristics for green chilli. Drying Technol. 20: 489- 505.

Kemp, I. C. 2007. Humidity effects in solids drying processes. Measurement and Control. 40(9): 268-271.

Mahlia, T. M. I., Cheng, L. W., Salikka, L. C. S., Lim, C. L., Hasan, M. H., and Hamdani, U. 2012. Drying Garcina atroviridis using waste heat from condenser of split room air conditioner. International Journal of Mechanical and Materials Engineering. 7(2): 171-176.

Misha, S., Mat, S., Ruslan, M. H., Sopian, K., and Salleh, E. 2013. The effect of drying air temperature and humidity on the drying kinetic of kenaf core. Applied Mechanics and Materials. 315: 710-714.

Putra, G. M. D., Sutoyo, M., Hartini, S. 2014. Uji kinerja alat pengering efek rumah kaca (ERK) hybrid dengan tungku biomassa sebagai sistem pemanas tambahan untuk pengeringan biji pala (Myristica sp.). Jurnal Teknik Pertanian Lampung. 3(2): 183-194.

Putra, M. Y. 2020. Meluruskan Informasi Khasiat Jahe Merah. (http://lipi.go.id/berita/MeluruskanInformasi-Khasiat-Jahe-Merah/21972) [Diakses tanggal 4 April 2020].

Rahmanto, D. E. 2011. "Rancang Bangun Alat Pengering Dengan Memanfaatkan Panas Kondensor AC Ruangan (Kasus Pengeringan Chips Kentang)". Tesis. Sekolah Pascasarjana Institut Pertanian Bogor, Bogor.

Rifkowaty, E. E, dan Martanto. 2016. Minuman fungsional serbuk instan jahe (Zingiber officinale Rosc) dengan 
variasi penambahan ekstrak bawang mekah (Eleutherine Americana Merr) sebagai pewarna alami. Jurnal Teknik Pertanian Lampung. 4(4): 315-324.

Rozana, Hasbullah, R., and Muhandri, T. 2016. Response of drying temperature on drying rate and quality of dried candied mango (Mangifera indica L.). JTEP. 4(1): 59-66.

Sari, I. N., Warji, Novita, D. D. 2014. Uji kinerja alat pengering hybrid tipe rak pada pengeringan chip pisang kepok. Jurnal Teknik Pertanian Lampung. 3(1): 59- 68 .

Sari, L. J. 2019. Uji Performansi Alat Pengering Gabah Tipe Dmp-1 dengan Penambahan Batu Alor Hitam pada Ruang Kolektor dan Ruang Pengering Sebagai Penyimpan Panas. Jurnal Keteknikan Pertanian Tropis dan Biosistem. 5(3): 84-91.

Suhendar, E., Tamrin, Novita, D. D. 2017. Uji kinerja alat pengering tipe rak pada pengeringan chip sukun menggunakan energi listrik. Jurnal Teknik Pertanian Lampung. 6(2): 125-132.

Susanti, T. M. I., dan Panunggal, B. 2015. Analisis antioksidan, total fenol, dan kadar kolesterol pada kuning telur asin dengan penambahan ekstrak jahe. Journal of Nutrition College. 4(2): 636-644.

Syam, H., Jamaluddin, Rais, M., dan Lestari, N. 2019. Potensi panas terbuang kondensor AC sebagai sumber pemanas pada cabinet dryer. Prosiding Seminar Nasional LP2M UNM 2019. 759-764.

Taib, G., Said, G. dan Wiraatmadja, S. 1988. Operasi Pengeringan pada Pengolahan Hasil Pertanian. Mediyatama Sarana Perkaya, Jakarta.

Triwahyudi, S. 2009. "Kajian Pengering Surya Efek Rumah Kaca (ERK)Hybrid dengan Rak Berputar secara Vertikal untuk Pengeringan Kapulaga Lokal (Amomum cardamomum wild)". Tesis. Sekolah Pascasarjana Institut Pertanian Bogor, Bogor.

Yadollahinia, A. R., Omid, M., and Rafiee, S. 2008. Design and fabrication of experimental dryer for studying agricultural products. International Journal of Agriculture and Biology. 10(1): 61-65.

Zamharir, Sukmawaty, dan Priyati, A. 2016. Analisis pemanfaatan energi panas pada pengeringan bawang merah (Allium ascalonicum 1.) dengan menggunakan alat pengering efek rumah kaca (ERK). Jurnal Ilmiah Rekayasa Pertanian dan Biosistem. 4(2): 264-274. 